\title{
Existential and Virtuous Effects of Religiosity on Mental Health and Aggressiveness among Offenders
}

\author{
Sung Joon Jang ${ }^{1, *(\mathbb{D})}$, Byron R. Johnson ${ }^{1}$, Joshua Hays ${ }^{1}$, Michael Hallett ${ }^{2}$ and Grant Duwe ${ }^{3}$ \\ 1 Institute for Studies of Religion, Baylor University, Waco, TX 76798, USA; byron_johnson@baylor.edu (B.R.J.); \\ william_hays@baylor.edu (J.H.) \\ 2 Department of Criminology \& Criminal Justice, University of North Florida, Jacksonville, FL 32224, USA; \\ mhallett@unf.edu \\ 3 Research and Evaluation, Minnesota Department of Corrections, St. Paul, MN 55108, USA; \\ grant.duwe@state.mn.us \\ * Correspondence: sung_joon_jang@baylor.edu; Tel.: +1-254-710-1691
}

Received: 16 May 2018; Accepted: 3 June 2018; Published: 6 June 2018

\begin{abstract}
Although prior research tends to show that religion has a salutary effect on mental health and a preventive effect on crime, studies explaining the religious effect, particularly those on offenders, have been limited. To address the issue, we examine whether religiosity is inversely related to negative emotions and aggressiveness among prison inmates. Additionally, we assess whether the relationships are attributable to an inmate's sense of meaning and purpose in life and/or their virtues. Specifically, we hypothesize that religiosity is inversely related to feelings of depression and anxiety and the intention of engaging in interpersonal aggression. We also hypothesize these relationships to be mediated by existential belief in life's meaning and purpose and virtues (compassion, forgiveness, gratitude, purpose of God, and gratitude to God). We tested our hypotheses using survey data collected from a random sample of male inmates from three prisons in Texas, applying latent-variable structural equation modeling. We found that the existential belief explained the effect of religiosity on negative emotional states and intended aggression. In addition, forgiveness and gratitude mediated the effect on state anxiety, whereas purpose in God and gratitude to God mediated the effect on state depression. Substantive and practical implications of our findings are discussed.
\end{abstract}

Keywords: religiosity; meaning and purpose in life; compassion; forgiveness; gratitude; depression; anxiety; aggression; prison; offender

\section{Introduction}

As a "total institution", prison is expected to have a detrimental impact on mental health among inmates, because upon entrance, they are stripped of supports taken for granted in the outside world and their identity becomes mortified as a result of a series of degradations of self (Goffman 1961). The mortification of self, along with a sense of guilt, shame, and hopelessness, is likely to generate a loss of meaning and purpose in life, which results in feelings of depression and anxiety among inmates. These negative emotions are also known to be positively associated with various forms of deviance in prison, such as infractions and suicide (Agnew 2006; Blevins et al. 2010). Researchers have found that religion tends to reduce not only prison misconduct, but also reoffending after release from prison (Hallett et al. 2017; Johnson 2011). Explanations for these religious effects, however, have been understudied.

To address the limitations of prior research, we propose to examine whether religion has prosocial effects on mental health and aggressiveness among offenders in prison, and whether religious effects, if found significant, are attributable to two potential outcomes associated with involvement in religion: 
a sense of meaning and purpose in life, and personal virtues. Specifically, we first hypothesize that religiosity is inversely related to feelings of depression and anxiety and the behavioral intention to engage in aggressive behavior toward other inmates. It is also hypothesized that these inverse relationships are explained by existential belief in life's meaning and purpose and virtues, such as compassion, forgiveness, and gratitude. To test these hypotheses, we analyzed survey data collected from a random sample of male offenders in three Texas prisons.

This paper begins with an overview of literature on religion, mental health, and crime. Based on the literature review, we then introduce our hypotheses, followed by a description of our sample, measurement, and analytic strategy (i.e., latent-variable structural equation modeling approach). Following this, we present results from estimating structural equation models, focusing on those for hypothesis testing. Substantive and practical implications of our findings, as well as suggestions for future research, are discussed.

\section{Religion and Mental Health}

The salutary effect of religious involvement on mental health has been well established in numerous studies from diverse disciplines, including psychology, psychiatry, epidemiology, sociology, and medicine (Koenig et al. 2012). Meta-analyses conducted by Hackney and Sanders (2003) and Sawatzky et al. (2005) show that the positive relationship between religiosity and psychological well-being was found across diverse definitions of religiosity and mental health, while the size of the relationship varied across different measures. A systematic review of 850 studies on religion and mental health by Moreira-Almeida et al. (2006) confirmed that religiosity tends to be inversely related to depression and suicidality, as well as being positively associated with emotional well-being. Levin (2010) review of psychiatric and mental health research on religion drew much the same conclusion.

Researchers tend to attribute religiosity's preventive function in relation to psychological distress to prosocial outcomes of religious involvement. In his theory of religious effects among adolescents, Smith (2003b) identified outcomes that would also explain the positive influence of religion in the lives of adults. For example, different religious traditions promote moral directives of self-control and personal virtue, such as compassion and forgiveness. Once internalized, these moral orders are reinforced in religious communities, where social support and positive role models guide life choices (e.g., avoiding drug use, helping others, and seeking reconciliation instead of vengeance). In this way, they reduce stressors and thus lessen psychological distress. Religions also "promote a variety of beliefs and practices [e.g., gratitude in adversity and forgiveness] that can help believers cope with the stress of difficult situations ... , to process difficult emotions, and to resolve interpersonal conflicts" (p. 23), thereby enhancing psychological well-being.

Prior research provides empirical evidence for the proposition that social support is a key mediator between stressors and psychological distress (Aneshensel 1992; Mirowsky and Ross 2003; Pearlin 1989), and partly explains the inverse relationship between religiosity and distress (e.g., Hayward and Krause 2014; Jang and Johnson 2004; Krause et al. 1999). Similarly, the intersection of the psychology of religion, positive psychology, and the psychology of emotion suggests such a causal link; that is, religion has a salutary effect via its promotion of virtues or, in short, a "virtuous effect" on mental health. Stated differently, religion fosters virtues, such as forgiveness, gratitude, compassion, and humility (Batson et al. 1999; Davis et al. 2017; Emmons and Paloutzian 2003; Krause 2018; McCullough 2000; Roberts 2004; Rye et al. 2000), and those virtues contribute to subjective well-being (Emmons and Crumpler 2000; Emmons and McCullough 2003; Froh et al. 2008; McCullough 2000). Though the religion/virtue/wellbeing link has not been studied often, compassion has been found to mediate the relationship between intrinsic religion and mental health, measured by depressive symptoms and perceived stress (Steffen and Masters 2005; see Krause (2018) for how humility and forgiveness explain the relationship between church attendance and physical health).

Besides the virtuous effect, researchers have also examined what we call the "existential effect" of religion by testing whether religion enhances mental health via its contribution to a human's existential 
need for meaning and purpose in life. According to Frankl (Frankl 1984; 1986), meaning in life is essential to the spiritual (not necessarily religious) dimension of human life, and when the innate desire of "will to meaning" (Frankl 1984, p. 121) is not satisfied, it results in "existential frustration" (p. 123). Though it is not in itself a mental disease, existential frustration can negatively affect mental health unless the innate desire for meaning in life is met. Meaning could be claimed based on anything, but according to Frankl (Frankl 1984), the "true meaning of life" (p. 133) should be self-transcendent (i.e., discovered outside of the individual). For this reason, religion is a major source of ultimate meaning in life (Batson and Stocks 2004; Fry 2000; Martos et al. 2010), although it is not a necessary condition for having a sense of meaning in life, as meaning may come from outside of religion (e.g., caring for the environment or volunteering for people in need).

Consistent with Frankl's propositions, George et al. (2002) suggest that the relationship between religious involvement and health, both mental and physical, can be partly explained by a sense of meaning, or what Ellison (1991) calls "existential coherence". Furthermore, McKnight and Kashdan (2009) propose that purpose-a self-organizing life aim—provides a sense of meaning, as well as stimulating goals and managing behaviors, which in turn contribute to mental and physical well-being. Previous research not only provides empirical evidence that religiosity is positively related to meaning and purpose in life, but also that the sense of meaning and purpose in life is positively associated with subjective well-being. For example, Steger and Frazier (2005) found that meaning in life mediated the relation between religiousness and life satisfaction (see also Bernard et al. 2017). Similarly, Jang (2016) reported not only a positive correlation between religiosity and "existential spirituality," a belief in ultimate meaning and purpose in life, but also an inverse relationship between existential belief and symptoms of anxiety-related disorders (see also Wang et al. 2016). While religion was not examined, a recent study of three prisons in Belgium found that the experience of loss of meaning was positively associated with distress among prison inmates (Vanhooren et al. 2017).

\section{Religion and Crime}

In his theory explaining religious effects, Smith (2003b) proposed a preventive effect on crime, as well as a salutary effect on mental health, as religion provides dense networks of social control. In fact, criminologists have used theories of not only deterrence and control, but also social learning and strain to explain the religiosity-crime relationship, positing that the predictors of crime mediate the relationship (Johnson and Jang 2010). That is, religiosity is hypothesized to decrease crime by increasing fear of punishment, conventional bonds, and self-control (Gibbs 1986; Gottfredson and Hirschi 1990; Hirschi 1969) and decreasing negative emotional reactions to strains, as well as deviant definitions and peer associations (Agnew 2006; Akers 2009). Previous studies and their synthesis via systematic review and meta-analysis provide empirical support for this hypothesis (Baier and Wright 2001; Burkett and Warren 1987; Desmond et al. 2011; Evans et al. 1995; Jang and Johnson 2011; Jang and Franzen 2013; Johnson et al. 2001; Johnson and Jang 2010; Kelly et al. 2015; Reisig et al. 2012; Ulmer et al. 2012), although the religiosity-crime relationship often remains significant after controlling for crime predictors and past criminality, as well as sociodemographic backgrounds.

A religion-crime relationship that remains significant after criminological predictors and statistical controls are taken into account implies that explaining the effects of religion on crime may require other non-criminological factors; for example, variables of religious process, such as religious coping (Johnson and Jang 2010). There could also be other non-religious factors, such as virtue and meaning and purpose in life, which criminologists have rarely examined, with the exception of self-control (e.g., Desmond et al. 2013). For instance, compassion, a strongly positive view toward the welfare of others and a desire to alleviate their suffering with an attempt to transcend all self-centered needs (Steffen and Masters 2005), is likely to decrease crime as it contradicts the very nature of crime, self-centeredness and insensitivity toward the suffering of others (Gottfredson and Hirschi 1990). Similarly, people who exhibit a sense of ultimate, self-transcendent meaning and purpose in life are less likely to engage in crime than those who do not, since crime hardly has any existential significance. 
While the existential effect of religion on crime has yet to be examined, the relevance of meaning and purpose in life to the study of desistance from crime has been proposed. In their "theory of existential identity transformation", built on Frankl (Frankl 1984), Jang and Johnson (2017) argue that all humans, including offenders, are spiritual or existential beings in the sense that we have an innate need to live meaningful lives, and thus search for narratives that arrange our actions into organized wholes in a way that bestows meaning in actions. We all have a "will to meaning" even though we are different in terms of spirituality (i.e., the extent of awareness of the existential need and pursuit of meaning to live accordingly). Therefore, Jang and Johnson posit that an offender's identity transformation should occur in the existential, as well as cognitive and emotional, dimensions of self-identity for criminal desistance (Giordano et al. 2002, 2007; Paternoster and Bushway 2009).

A recent study yielded a partial test of Jang and Johnson (2017) proposition by examining whether (1) individual religiosity was positively associated with existential, as well as cognitive and emotional, identity transformations; and (2) the identity transformations were inversely related to disciplinary convictions among offenders in a maximum-security prison (Jang et al. 2018; see also Hallett et al. 2017). The results showed that not only religious involvement, but also religious conversion were positively associated with the extent of existential identity transformation, which was in turn inversely related to disciplinary convictions via emotional transformation, particularly transformation in negative emotional identity. Thus, the study provides preliminary evidence of the existential effect of religion on a behavior analogous to crime, prison misconduct.

\section{The Present Study}

Based on the literature reviewed above, we intend to examine whether religiosity has a salutary effect on mental health and a preventive effect on aggression and, if so, whether the effects are in part virtuous and existential (i.e., attributable to virtues and a sense of meaning and purpose in life that religion is expected to promote and enhance). Among various ways to operationalize mental health, this study focuses on two negative emotional states, state depression and state anxiety; that is, the lower the levels of state depression and anxiety, the better the mental health. Next, aggression is measured in terms of behavioral intention; that is, an individual's intention to engage in aggressive behavior or, in short, intended aggression. ${ }^{1}$ Finally, we examine three virtues deemed particularly relevant to the explanation of crime or an analogous behavior (e.g., aggression): compassion, forgiveness, and gratitude, which previous studies found to be positively associated with psychological well-being (see Section 2). Similarly, a sense of meaning and purpose in life is expected to enhance mental health and reduce crime and deviance.

Specifically, being the combination of empathy and altruism, compassion is likely to increase positive relations with others, not only the object of compassion but also those who support and commend compassionate behavior, which in turn contributes to mental health (Steffen and Masters 2005). Recognizing and appreciating an external source of an unearned gain in life (i.e., gratitude) tends to complete enjoyment of the positive outcome and generate more fulfilling experiences, which should increase emotional well-being (Emmons and McCullough 2003; Froh et al. 2008). Forgiveness is expected to enhance mental health partly because it repairs relations that have been damaged by interpersonal offenses (Krause 2018). A sense of meaning and purpose in life also has a salutary effect as it eliminates existential crisis (Frankl 1984; Krause 2018).

While relationships between virtues or existential belief and crime have rarely been explored, they are likely to be negative according to the nature of crime. For example, a compassionate act is the direct opposite to crime, which "often results in pain or discomfort for the victim" (Gottfredson and

1 We decided to measure aggression in terms of behavioral intention rather than actual behavior of the past to establish causal ordering between the key independent (current measure of religiosity; see Section 5.2. below) and dependent variables (aggression likely in the future). In addition, underreporting associated with self-reported instances of aggression was partly a concern, while a measure of behavioral intention was not fully immune to the potential reporting bias. 
Hirschi 1990, p. 89). Similarly, forgiveness, restoring broken relationships (Krause 2018), and gratitude that involves empathic emotions (Emmons and McCullough 2003) are inconsistent with criminality. Moreover, having a sense that one's life matters and has a purpose or mission is cognitively dissonant with stealing and hurting or killing other people (Steger and Frazier 2005). Thus, the three virtues and existential belief are all expected to be inversely related to crime.

In summary, we test the following hypotheses.

Hypothesis 1. Religiosity is inversely related to state depression and anxiety, and intended aggression.

Hypothesis 2. The inverse relationships between religiosity, on the one hand, and state depression and anxiety and intended aggression, on the other, are in part mediated by a sense of meaning and purpose in life and the virtues of compassion, forgiveness, and gratitude.

\section{Methods}

\subsection{Sample}

The data used to test our hypotheses came from a survey conducted at three maximum-security all-male prisons in Texas in February 2017. Several days before the survey was administered, the Texas Department of Criminal Justice (TDCJ) provided us with a five-percent random sample of each prison's population, which included 244 offenders. Two-thirds of them $(163,66.8 \%)$ agreed to participate in the study. T-tests revealed that inmates who participated were, in general, not significantly different from those who did not participate, with a few exceptions. Specifically, they were not different in race and ethnicity; intelligence quotient (I.Q.) score; participation in vocational and cognitive intervention programming; number of confinements in jail; number of total, as well as property, drug, and other offenses; and minor and major infractions between 2007 and 2016. On the other hand, the participants were younger and higher than non-participants on the educational achievement (EA) score $^{2}$, participation in academic programming, and number of confinements in prison, but lower on number of violent offenses. ${ }^{3}$ These differences need to be kept in mind in interpreting the results presented in the next section (Section 6).

\subsection{Measurement}

For the key exogenous variable, religiosity, a scale was constructed by summing standardized scores of five items: perceived closeness to God, religious salience (i.e., perceived importance of religion), religious service attendance, praying outside of religious services, and reading a sacred text in private. The items had high factor loadings, ranging from 0.55 to 0.86 , and high internal reliability, Cronbach's alpha $(\alpha)$ of 0.81 (see Appendix A Table A1 for details of all scales).

To measure a sense of meaning and purpose in life, we created a scale of presence of meaning using four items of the Search and Presence of Meaning scale from Steger et al. (2006). They were all clustered on a factor with high loadings (from 0.68 to 0.81 ) and a high inter-item reliability $(\alpha=0.83$ ). The mediators of virtue were also measured using items of existing scales. Five items of compassion and two items of forgiveness came from the Landmark Spirituality and Health Survey from Krause et al. (2016). Compassion items had high factor loadings (from 0.49 to 0.82 ) and good internal reliability $(\alpha=0.78$ ), and the two forgiveness items also had good reliability $(\alpha=0.74)$. A scale of gratitude was constructed

2 The score measures the grade level achieved based on an assessment by the prison's school district.

Specifically, on average, study participants were about four and a half years younger ( $42.85 \mathrm{vs}$. 47.43$)$ and about one grade higher in education ( $8.77 \mathrm{vs}$. 7.64$)$, had participated more in academic programming ( $0.45 \mathrm{vs} .0 .21$ ), and had been in prison (1.91 vs. 1.61) slightly more often than non-participants, whereas the former had committed lower number of violent offenses than the latter (1.74 vs. 2.34). 
based on three items drawn from Gratitude Questionnaire-6 from McCullough et al. (2002), which had high loadings (from 0.65 to 0.99 ) and good reliability $(\alpha=0.78$ ).

Two additional scales of virtue were created in relation to God. One was a three-item scale of God's purpose in life with items showing high factor loadings (from 0.86 to 0.89 ) and excellent reliability $(\alpha=0.91)$, and the other was a two-item scale of gratitude to God with good reliability $(\alpha=0.74)$.

To construct an eight-item scale of state depression, we employed seven items of the Center for Epidemiologic Studies Depression (CES-D) Scale (Radloff 1977) and an item about feeling suicidal, which had high factor loadings (from 0.48 to 0.90 ) and high reliability ( $\alpha=0.87$ ). On the other hand, state anxiety was measured by the seven-item scale of General Anxiety Disorder (GAD-7) from Spitzer et al. (2006), with items having high factor loadings (from 0.68 to 0.84 ) and excellent inter-item reliability ( $\alpha=0.91$ ).

The other ultimate endogenous variable, intended aggression, was measured using the vignette method. That is, survey respondents were given a hypothetical situation (see below) and asked how likely they were to act in the same manner as the character in the scenario, based on a six-point Likert scale $(1=$ not likely at all [0\%], $2=$ very unlikely, $3=$ unlikely, $4=$ likely, $5=$ very likely, $6=$ certainly $[100 \%])$.

It's Sunday afternoon. Mike is watching an National Football League (NFL) football game in the prison dayroom with other inmates. During a halftime break, Mike goes to the restroom. To reserve his seat, he asks a friend to "hold it down" for him. When Mike comes back, Joe is in his seat. Mike asks Joe to leave because it is his seat. Joe says he can sit anywhere he wants. Mikes asks Joe to leave one more time. This time Joe ignores Mike. Meanwhile, everyone is watching what's going on. Feeling not only dissed but also that he is right, Mike gets into an argument with Joe.

Finally, we controlled for the respondent's sociodemographic and criminal background characteristics likely to be correlated with the key exogenous (religiosity) and ultimate endogenous variables (state depression, state anxiety, and intended aggression): age, race (the dummy variables of black and Hispanic, with white being the reference category), EA (educational achievement) score, number of total offense committed, length of sentence (in years), and religious affiliation (using dummy variables of Catholic, other religion, and no religion, with Protestant being the reference category).

\subsection{Analytic Strategy}

We applied a structural equation modeling approach to estimate the hypothesized relationships. Latent-variable modeling is appropriate given that our key concepts are all abstract and thus not observable. It also enables us to control for measurement errors so we can test hypotheses based on more valid and reliable results than those that would be produced by manifest-variable modeling (Bollen 1989).

For model estimation, we employed Mplus 8 (Muthén and Muthén 2017), which incorporates Muthén (1983) "general structural equation model" and full information maximum likelihood (FIML) estimation, which allows for not only continuous, but also dichotomous and ordered polytomous variables to be indicators of latent variables. Because variables were measured by ordered categorical (e.g., religious service attendance) and continuous variables (e.g., age), we used the "maximum likelihood parameter estimates with standard errors ... that are robust to non-normality and non-independence of observations" (Muthén and Muthén 2017, p. 668). We employed FIML to treat missing data, which tends to produce unbiased estimates, such as multiple imputations (Baraldi and Enders 2010; Graham 2009).

For model fit, besides the chi-square $\left(\lambda^{2}\right)$ statistic, we report three types of fit index-incremental (CFI: comparative fit index), absolute (SRMR: standardized root mean squared residual), and parsimonious fit index (RMSEA: root mean square error of approximation). A model was determined to have a good fit to data if one of two joint criteria suggested by Hu and Bentler (1999) was met: (CFI $\geq 0.95$ and SRMR $\leq 0.08$ ) or (SRMR $\leq 0.08$ and RMSEA $\leq 0.06$ ).

Finally, for statistical significance, we conducted a one-tailed test because the direction of the relationship was hypothesized using two levels of significance $(\alpha), 0.05$ and 0.01 . 


\section{Results}

Table 1 shows the frequency and percentage distributions of nominal-level variables and the descriptive statistics of others, along with the number of observations for each variable. The survey respondents were, on average, approximately 43 years old, with the youngest and oldest being 21 and 79 , respectively, and with $25.2 \%$ white, $48.5 \%$ black, and $26.4 \%$ Hispanic. The average grade level completed was less than the ninth grade, whereas they had committed an average of three offenses in total and were serving a sentence, on average, of 29 years at the time of the survey. Approximately $90 \%$ of the sample reported a religious affiliation: $69.6 \%$ Christian and $21.5 \%$ non-Christian religion (including 5.0\% Islam, 1.9\% Judaism, 1.3\% Eastern religion, and 13.3\% "other"; not shown in table). It is worth noting that while respondents typically said there was roughly a $50 \%$ chance (i.e., 3.53 , about the midpoint between "unlikely" [=3] and "likely" [=4]) of getting into an argument in such a situation as described in the scenario, their reported probabilities were distributed across all six levels of likelihood: 19.9\% "not likely at all (0\%)", 12.2\% "very unlikely", 13.5\% "unlikely", 22.4\% "likely", $13.5 \%$ "very likely", and $18.6 \%$ "certainly (100\%)" (not shown in table). This observation might suggest that there was minimal reactivity due to social desirability on the part of respondents.

For hypothesis testing, we began with estimating two baseline models; one included only religiosity to explain state depression, state anxiety, and intended aggression (Baseline Model 1), and the other added sociodemographic and criminal background controls to the first baseline model (Baseline Model 2). We analyzed the three ultimate endogenous variables simultaneously by specifying their relationships as correlations via their residuals. Next, we introduced mediators (five virtue variables and the scale of existential belief) to the second baseline model, one at a time, to examine whether they individually explained the relationships between religiosity and the ultimate endogenous variables (Mediation Models 1 to 6). Finally, all six mediators were included together to estimate their collective explanation of religious effects on negative emotional states and intended aggression (Full Model). In this final model, relationships among the mediators were specified as residual correlations, like those among the ultimate endogenous variables.

Table 2 presents results from estimating the baseline and individual mediation models; with standardized coefficients and their standard error (S.E.) in parenthesis. All models had good fit to data, meeting one of the two joint criteria, SRMR $\leq 0.08$ and RMSEA $\leq 0.06$. First, when we included only religiosity in model (Baseline Model 1), we found it had inverse relationships with all three ultimate endogenous variables, as anticipated; that is, the higher religiosity, the less likely to report state depression, state anxiety, and intended aggression. The religious effects on the three dependent variables were similar in size (i.e., $-0.23,-0.22,-0.21$ ). Next, controlling for sociodemographic and criminal background variables, we found two of the three coefficients remained significant, with the exception being the effect of religiosity on state depression (Baseline Model 2). Thus, Hypothesis 1 received support with respect to state anxiety and intended aggression, but not state depression. That is, more religious offenders were less likely, when compared with their less religious or non-religious counterparts, to (1) have experienced anxiety during the last two weeks prior to the survey, and (2) get into an argument with another inmate if they had been put in a situation as described in the scenario, while religiosity made no significant difference among the offenders with respect to state depression. 
Table 1. Descriptive Statistics of Variables Included in Analysis $(n=163)$. CES-D-Center for Epidemiologic Studies Depression; GAD-7-General Anxiety Disorder.

\begin{tabular}{|c|c|c|c|c|c|c|}
\hline \multicolumn{2}{|l|}{ Variable } & $n$ & Mean/\% & S.D. & Min. & Max. \\
\hline \multicolumn{2}{|c|}{ Age } & 163 & 42.85 & 12.45 & 21 & 79 \\
\hline \multicolumn{2}{|c|}{ EA (educational achievement) score } & 157 & 8.77 & 3.02 & 1 & 13 \\
\hline \multicolumn{2}{|c|}{ Total offense } & 163 & 3.30 & 2.24 & 1 & 11 \\
\hline \multicolumn{2}{|c|}{ Sentence length (in years) } & 163 & 29.10 & 20.97 & 2 & 60 \\
\hline \multirow[t]{4}{*}{ Race } & White & 41 & $25.2 \%$ & & & \\
\hline & Black & 79 & $48.5 \%$ & & & \\
\hline & Hispanic & 43 & $26.4 \%$ & & & \\
\hline & Total & 163 & $100.0 \%$ & & & \\
\hline \multirow[t]{5}{*}{ Religious affiliation } & Protestant & 78 & $49.4 \%$ & & & \\
\hline & Catholic & 32 & $20.2 \%$ & & & \\
\hline & Other religion & 34 & $21.5 \%$ & & & \\
\hline & No religion & 14 & $8.9 \%$ & & & \\
\hline & Total & 158 & $100.0 \%$ & & & \\
\hline & 151 & 3.85 & 1.10 & 1 & 5 \\
\hline \multicolumn{2}{|c|}{$\begin{array}{l}\text { Religiosity } 1 \text {. Perceived closeness to God } \\
\text { 2. Frequency of religious service attendance }\end{array}$} & 153 & 5.42 & 2.54 & 1 & 8 \\
\hline \multicolumn{2}{|c|}{ 3. Frequency of prayer outside of religious service } & 152 & 4.84 & 1.52 & 1 & 6 \\
\hline \multicolumn{2}{|c|}{ 4. Perceived importance of religion } & 151 & 3.98 & 1.25 & 1 & 5 \\
\hline \multicolumn{2}{|c|}{ 5. Frequency of reading the Bible or other sacred book } & 153 & 5.86 & 2.52 & 1 & 8 \\
\hline \multicolumn{2}{|c|}{ Presence of meaning 1. I understand my life's meaning } & 160 & 5.29 & 1.62 & 1 & 7 \\
\hline \multicolumn{2}{|c|}{ 2. My life has a clear sense of meaning } & 162 & 5.36 & 1.51 & 1 & 7 \\
\hline \multicolumn{2}{|c|}{ 3. A sense of what makes my life meaningful } & 162 & 5.68 & 1.32 & 1 & 7 \\
\hline \multicolumn{2}{|c|}{ 4. I have discovered a satisfying life purpose } & 162 & 5.25 & 1.68 & 1 & 7 \\
\hline \multicolumn{2}{|c|}{ Compassion 1 . Try to imagine how others feel in a difficult situation } & 160 & 3.16 & 0.67 & 1 & 4 \\
\hline \multicolumn{2}{|c|}{ 2. Feel compelled to help others by going out of my way } & 159 & 3.18 & 0.73 & 1 & 4 \\
\hline \multicolumn{2}{|c|}{ 3. Not enough to feel sorry for others in trouble } & 157 & 3.12 & 0.75 & 1 & 4 \\
\hline 4. Feel & ners even when they caused the prob. & 159 & 2.70 & 0.86 & 1 & 4 \\
\hline 5. Feel & ners even when they have hurt me & 157 & 2.48 & 0.81 & 1 & 4 \\
\hline Forgiveness: I have $\mathrm{f}$ & se who hurt me. & 158 & 3.22 & 0.83 & 1 & 4 \\
\hline Gratitude 1. Everyth & ateful for would make a long list & 160 & 5.59 & 1.86 & 1 & 7 \\
\hline 2. I am gra & de variety of people & 159 & 5.78 & 1.57 & 1 & 7 \\
\hline & Variable & $n$ & Mean/\% & S.D. & Min. & Max. \\
\hline God's purpose 1 . Go & this life for a purpose & 151 & 3.55 & 0.78 & 1 & 4 \\
\hline $2 . \mathrm{G}$ & cific plan for my life & 150 & 3.66 & 0.66 & 1 & 4 \\
\hline 3. G & $\mathrm{n}$ for everything that happens to me & 151 & 3.54 & 0.76 & 1 & 4 \\
\hline Gratitude to God 1. & Jod for all He has done for me & 153 & 4.58 & 0.81 & 1 & 5 \\
\hline & seen richly blessed by God & 154 & 3.93 & 1.33 & 1 & 5 \\
\hline & all He has done for my family/friends & 153 & 4.54 & 0.80 & 1 & 5 \\
\hline Depression 1. Could & the blues, even with the help of other & 160 & 2.75 & 1.26 & 1 & 5 \\
\hline (CES-D) 2. Felt depr & & 160 & 2.62 & 1.15 & 1 & 5 \\
\hline 3. Felt sad & & 160 & 2.74 & 1.09 & 1 & 5 \\
\hline 4. Not felt 1 & nd poor appetite & 159 & 2.24 & 1.26 & 1 & 5 \\
\hline 5. Felt that & did was an effort & 159 & 3.28 & 1.24 & 1 & 5 \\
\hline 6. My sleep & & 157 & 3.02 & 1.24 & 1 & 5 \\
\hline 7. Could no & & 158 & 2.52 & 1.16 & 1 & 5 \\
\hline 8. Felt suici & & 160 & 1.31 & 0.81 & 1 & 5 \\
\hline Anxiety 1 . Feeling $\mathrm{n}$ & ous & 159 & 2.85 & 1.28 & 1 & 7 \\
\hline (GAD-7) 2. Not bein & p or control worrying & 159 & 2.54 & 1.21 & 1 & 5 \\
\hline 3. Trouble $\mathrm{r}$ & & 159 & 2.64 & 1.24 & 1 & 5 \\
\hline 4. Being so & it is hard to sit still & 158 & 2.34 & 1.26 & 1 & 5 \\
\hline 5. Worrying & bout different things & 160 & 2.83 & 1.27 & 1 & 5 \\
\hline 6. Becomin & oyed or irritable & 159 & 2.72 & 1.23 & 1 & 5 \\
\hline 7. Feeling a & mething awful might happen & 159 & 2.54 & 1.23 & 1 & 5 \\
\hline Intended aggression & & 156 & 3.53 & 1.76 & 1 & 6 \\
\hline
\end{tabular}


Table 2. Baseline and Mediation Models of State Depression, State Anxiety, and Intended Aggression ( $n=163)$; with Standardized Coefficients and Standard Errors (in parentheses).

\begin{tabular}{|c|c|c|c|c|c|c|c|c|}
\hline & \multicolumn{2}{|c|}{ Mediator } & \multicolumn{2}{|c|}{ State Depression } & \multicolumn{2}{|c|}{ State Anxiety } & \multicolumn{2}{|c|}{ Intended Aggression } \\
\hline Variable & $\beta$ & (S.E.) & $\beta$ & (S.E.) & $\beta$ & (S.E.) & $\beta$ & (S.E.) \\
\hline \multicolumn{9}{|l|}{ Baseline Model 1} \\
\hline Religiosity & & & $-0.23 * *$ & $(0.09)$ & $-0.22 * *$ & $(0.09)$ & $-0.21 * *$ & $(0.09)$ \\
\hline \multicolumn{9}{|c|}{ Model fit: Chi-square $=280.12,[184,0.00]^{\mathrm{a}} ;$ RMSEA $=0.06,[0.04,0.07]^{\mathrm{b}} ; \mathrm{CFI}=0.93 ;$ SRMR $=0.06$} \\
\hline \multicolumn{9}{|l|}{ Baseline Model 2} \\
\hline Age & & & -0.01 & $(0.10)$ & $-0.22 * *$ & $(0.09)$ & $-0.22 * *$ & $(0.08)$ \\
\hline Black & & & -0.13 & $(0.11)$ & -0.16 & $(0.09)$ & 0.06 & $(0.10)$ \\
\hline Hispanic & & & -0.04 & $(0.11)$ & -0.19 & $(0.11)$ & 0.04 & $(0.10)$ \\
\hline EA score & & & $-0.22 *$ & $(0.11)$ & -0.16 & $(0.10)$ & 0.02 & $(0.09)$ \\
\hline Total offense & & & -0.08 & $(0.10)$ & 0.02 & $(0.10)$ & -0.01 & $(0.08)$ \\
\hline Length of sentence & & & -0.02 & $(0.10)$ & -0.02 & $(0.09)$ & -0.06 & $(0.09)$ \\
\hline Catholic & & & 0.06 & $(0.12)$ & -0.01 & $(0.11)$ & 0.02 & $(0.09)$ \\
\hline Other religion & & & -0.07 & $(0.08)$ & 0.04 & $(0.08)$ & 0.01 & $(0.08)$ \\
\hline No religion & & & 0.02 & $(0.10)$ & -0.02 & $(0.09)$ & 0.01 & $(0.10)$ \\
\hline Religiosity & & & -0.18 & $(0.12)$ & $-0.21^{* *}$ & $(0.10)$ & $-0.20 *$ & $(0.10)$ \\
\hline \multicolumn{9}{|c|}{ Model fit: Chi-square $=537.68,[337,0.00] ;$ RMSEA $=0.06,[0.05,0.07] ;$ CFI $=0.88 ;$ SRMR $=0.06$} \\
\hline \multirow{5}{*}{$\begin{array}{l}\text { Mediation model } 1 \\
\text { Religiosity } \\
\text { Presence of } \\
\text { meaning }\end{array}$} & & & & & & & & \\
\hline & $0.46^{* *}$ & $(0.11)$ & -0.04 & $(0.14)$ & -0.07 & $(0.12)$ & -0.11 & $(0.12)$ \\
\hline & & & $-0.34^{* *}$ & $(0.11)$ & $-0.32 * *$ & $(0.11)$ & $-0.20 *$ & $(0.10)$ \\
\hline & & & \multicolumn{6}{|c|}{ Indirect Effect } \\
\hline & & & $-0.16^{* *}$ & $(0.06)$ & $-0.15^{* *}$ & $(0.06)$ & $-0.09 *$ & $(0.05)$ \\
\hline \multicolumn{9}{|c|}{ Model fit: Chi-square $=683.84,[446,0.00] ;$ RMSEA $=0.06,[0.05,0.07] ;$ CFI $=0.88 ;$ SRMR $=0.06$} \\
\hline \multirow{5}{*}{$\begin{array}{l}\text { Mediation mod } \\
\text { Religiosity } \\
\text { Compassion }\end{array}$} & & & & & & & & \\
\hline & $0.25 *$ & $(0.13)$ & -0.14 & $(0.12)$ & -0.21 * & $(0.11)$ & -0.13 & $(0.11)$ \\
\hline & & & \multirow{2}{*}{\multicolumn{6}{|c|}{ Indirect Effect }} \\
\hline & & & & & & & & \\
\hline & & & -0.05 & $(0.04)$ & -0.01 & $(0.03)$ & -0.07 & $(0.04)$ \\
\hline \multicolumn{9}{|c|}{ Model fit: Chi-square $=755.00,[479,0.00] ;$ RMSEA $=0.06,[0.05,0.07] ; \mathrm{CFI}=0.86 ; \mathrm{SRMR}=0.06$} \\
\hline \multirow{4}{*}{$\begin{array}{l}\text { Mediation model } 3 \\
\text { Religiosity } \\
\text { Forgiveness }\end{array}$} & & & & & & & & \\
\hline & $0.30 * *$ & $(0.12)$ & -0.14 & $(0.13)$ & -0.16 & $(0.11)$ & -0.16 & $(0.11)$ \\
\hline & & & $-0.17^{*}$ & $(0.09)$ & $-0.18^{* *}$ & $(0.08)$ & $-0.14^{*}$ & $(0.08)$ \\
\hline & & & -0.05 & \multicolumn{3}{|c|}{ Indirect Effect } & -0.04 & $(0.03)$ \\
\hline
\end{tabular}

Model fit: Chi-square $=552.73,[354,0.00] ;$ RMSEA $=0.06,[0.05,0.07] ; \mathrm{CFI}=0.88 ; \mathrm{SRMR}=0.06$

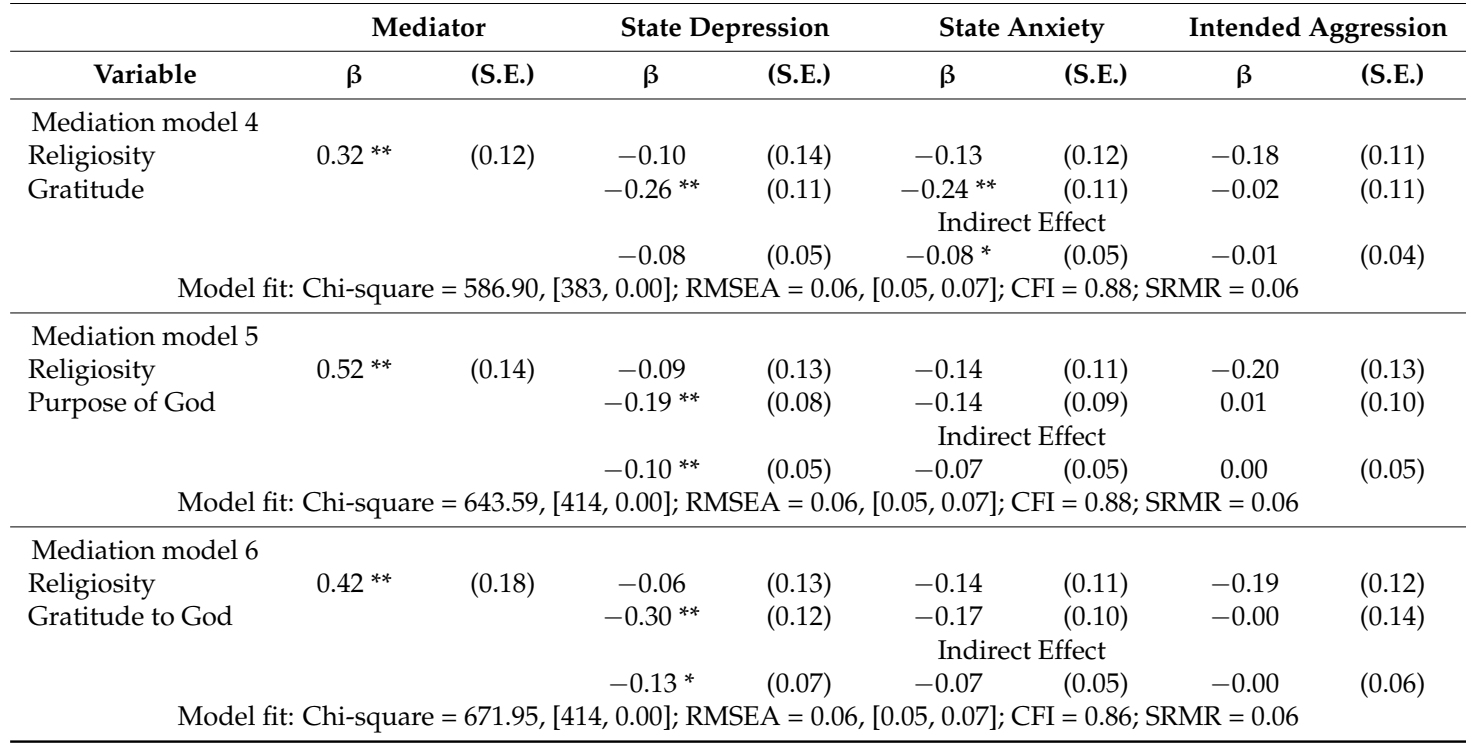

${ }^{\text {a }}$ Chi-square statistic's degrees of freedom and $p$-value; ${ }^{\mathrm{b}}$ Lower and upper limits of RMSEA's $90 \%$ confidence interval; ${ }^{*} p<0.05,{ }^{* *} p<0.01$ (one-tailed test). RMSEA—root mean square error of approximation; CFI—comparative fit index; SRMR—standardized root mean squared residual. 
The significant effects of religiosity on state anxiety and intended aggression became non-significant, however, when virtue variables were entered individually into the second baseline model - with the exception of compassion model (see Mediation Model 2, where the effect on anxiety remained the same, -0.21 , and was significant when compassion was added as mediator). In all mediation models, we found religiosity had a significant positive effect on the mediator, which in turn had a positive effect on the ultimate endogenous variables, with some exceptions. For example, religious offenders were more likely than non-religious offenders to report a sense of meaning and purpose in life $(-0.46$ in Mediation Model 1$)$, which tended to decrease the probability of reporting negative emotional states $(-0.34$ and -0.32$)$ and intended aggression $(-0.20)$. On the other hand, while religiosity was found to be positively associated with compassion ( 0.25 in Mediation Model 2), the virtue was inversely related to state depression $(-0.20)$ and intended aggression $(-0.27)$, but not state anxiety $(-0.04)$.

To test Hypothesis 2, we estimated indirect effects of religiosity on negative emotional states and intended aggression via each mediator. For instance, the indirect effects of religiosity on state depression, state anxiety, and intended aggression were mediated by a sense of meaning and purpose in life $(-0.16,-0.15$, and -0.09 , respectively), as anticipated based on significant associations both between religiosity and presence of meaning $(0.46)$ and between presence of meaning and the ultimate endogenous variables $(-0.34,-0.32$, and -0.20$)$. The indirect effect, however, was not always statistically significant, even when the mediator had significant relationships with both religiosity and the dependent variable. Compassion is a case in point; that is, although the virtue had significant relationships with religiosity $(0.25)$, state depression $(-0.20)$, and intended aggression $(-0.27)$, the indirect effects were found to not be significant ( -0.05 and -0.07 , respectively). This finding shows the importance of testing mediation hypotheses based on a statistical test of indirect effect, rather than separate examination of relationships involved in mediation for statistical significance.

In summary, the mediation hypothesis received full support in the presence-of-meaning model, but limited support in the virtue models; that is, the religious effects were existential and, to a lesser extent, virtuous in nature. Specifically, forgiveness and gratitude mediated only the effect of religiosity on state anxiety ( -0.06 and -0.08$)$, whereas purpose of God and gratitude to God explained only the effect on state depression $(-0.10$ and -0.13$)$. We failed to find significant mediation of compassion.

Finally, we estimated the full model including all six mediators, and the results are presented in Table 3 (see Appendix B for estimated measurement models). The final model also had good fit to data, meeting the joint criterion of SRMR $\leq 0.08$ and RMSEA $\leq 0.06$. First, consistent with what we found in individual mediation models (Table 2), religiosity was positively associated with existential belief and all five virtues: presence of meaning $(0.47)$, compassion $(0.27)$, forgiveness $(0.31)$, gratitude (0.36), purpose of God (0.53), and gratitude to God (0.43). While the two God-related virtues were expected to have relatively strong association with religiosity, it is noteworthy that religiosity had a similarly strong relationship with presence of meaning, which tends to confirm that religion is a major source of existential belief even among offenders. These results document that religious offenders are more likely to have a sense of meaning and purpose in life and virtuous characteristics than their non-religious counterparts.

Three of the six mediators were found to have significant relationships with two of the three ultimate endogenous variables. Presence of meaning and forgiveness were inversely associated with state anxiety $(-0.25$ and -0.17 , respectively), and compassion was inversely related to intended aggression $(-0.25)$. The inverse relationship that exists between presence of meaning and forgiveness and state anxiety tends to support the idea that (1) a sense of meaning and purpose in life is likely to decrease the chance of experiencing anxiety by avoiding existential crisis and frustration (Frankl 1984; Jang 2016; Vanhooren et al. 2017), and (2) forgiveness repairs relationships damaged by personal offenses, thereby reducing anxiety (Krause 2018). 
Table 3. Final Model of State Depression, State Anxiety, and Intended Aggression with All Six Mediators Included ( $n=163)$; with Standardized Coefficients.

\begin{tabular}{|c|c|c|c|c|c|c|c|c|c|}
\hline \multirow[b]{2}{*}{ Variable } & \multicolumn{6}{|c|}{ Mediating Endogenous Variable } & \multicolumn{3}{|c|}{ Ultimate Endogenous Variable } \\
\hline & Pres. of Meaning & Compassion & Forgiveness & Gratitude & Purpose of God & Gratitude to God & Depression & Anxiety & Intended Aggress \\
\hline Age & $0.20 * *$ & 0.10 & 0.07 & 0.11 & -0.03 & 0.16 & 0.08 & -0.15 & $-0.18^{* *}$ \\
\hline Black & 0.15 & 0.15 & 0.02 & $0.32 * *$ & $0.24 * *$ & 0.16 & -0.00 & -0.07 & 0.10 \\
\hline Hispanic & 0.16 & -0.00 & 0.01 & 0.15 & 0.05 & 0.06 & 0.02 & -0.13 & 0.06 \\
\hline EA score & -0.07 & -0.14 & -0.02 & 0.09 & -0.01 & 0.04 & -0.23 ** & -0.16 & -0.03 \\
\hline Total offense & -0.00 & 0.09 & 0.09 & 0.20 ** & -0.02 & -0.01 & -0.06 & 0.02 & 0.02 \\
\hline Length of sent. & -0.14 & 0.09 & 0.02 & -0.03 & -0.07 & -0.05 & -0.06 & -0.08 & -0.05 \\
\hline Catholic & 0.12 & 0.02 & 0.07 & 0.08 & 0.02 & 0.02 & 0.10 & 0.03 & 0.05 \\
\hline Other religion & 0.15 & 0.08 & 0.01 & -0.07 & -0.04 & -0.05 & -0.05 & 0.06 & 0.06 \\
\hline No religion & 0.12 & 0.17 & 0.03 & $0.17^{* *}$ & 0.03 & 0.13 & 0.09 & 0.01 & 0.06 \\
\hline Religiosity & $0.47^{* *}$ & 0.27 * & $0.31^{* *}$ & $0.36^{* *}$ & $0.53 * *$ & $0.43 * *$ & 0.10 & 0.02 & -0.08 \\
\hline Pre. of meaning & & & & & & & -0.20 & $-0.25 *$ & -0.18 \\
\hline Compassion & & & & & & & -0.08 & 0.09 & $-0.25^{* *}$ \\
\hline Forgiveness & & & & & & & -0.10 & $-0.17^{*}$ & -0.05 \\
\hline Gratitude & & & & & & & -0.10 & -0.08 & -0.02 \\
\hline Purpose of God & & & & & & & -0.13 & -0.13 & 0.01 \\
\hline \multirow[t]{3}{*}{ Gratitude to God } & & & & & & & -0.12 & -0.02 & 0.15 \\
\hline & & & & & & & \multicolumn{3}{|c|}{ Total indirect effect } \\
\hline & & & & & & & $-0.31 * *$ & $-0.25^{* *}$ & -0.11 \\
\hline
\end{tabular}

${ }^{\text {a }}$ Degrees of freedom and $p$-value; ${ }^{\mathrm{b}}$ Lower and upper limits of RMSEA's 90 percent confidence interval; ${ }^{*} p<0.05,{ }^{* *} p<0.01$ (one-tailed test). 
We also estimated the total indirect effect of religiosity via all six mediators to see whether existential belief and virtues collectively mediated the religious effect on the ultimate endogenous variables. We found the total indirect effects of religiosity on state depression and anxiety were significant ( -0.31 and -0.25 , respectively), while the religious effect on intended aggression was not significant. This finding seems to be consistent with the earlier finding that three mediators explained the religious effects on state depression (presence of meaning, purpose of God, and gratitude to God) and state anxiety (presence of meaning, forgiveness, and gratitude), while only one did the same on intended aggression (presence of meaning); that is, the more mediators found to be significant in the individual mediation model, the more likely the significant total indirect effect. In summary, when we tested Hypothesis 2 in terms of collective mediation, we found support for two of the three dependent variables: state depression and anxiety.

\section{Discussion and Conclusions}

Religion's salutary effect on mental health and preventive effect on crime are empirically well-established (e.g., Johnson and Jang 2010; Koenig et al. 2012), but those effects have not as often been studied among offenders as among people in the general population. This study intended not only to address the gap in prior research, but also to examine whether religious effects on mental health and aggression among offenders are attributable in part to personal virtues and existential belief in meaning and purpose in life, which religions tend to promote and enhance. While there is some evidence that religion has a virtuous and existential effect on mental health, the religion-crime relationship has not been explained in terms of existential belief and virtues, except for self-control.

In this study, we found that offenders' religiosity was positively related to a sense of meaning and purpose in life and virtuous characteristics (compassion, forgiveness, gratitude, purpose of God, and gratitude to God), which in turn tended to be inversely associated with the offenders' negative emotional states and intended aggression. When mediators were examined individually, offenders' existential belief was found to consistently explain the religious effect across all three dependent variables; that is, more religious offenders were less likely to report feelings of depression and anxiety and intention to engage in interpersonal aggression, because they were more likely to have a sense of meaning and purpose in life than their less or non-religious counterparts. This finding is in part consistent with previous research showing the psychologically detrimental impact of loss of meaning among prisoners (Vanhooren et al. 2017).

We found the religious effect to be existential and, to a lesser extent, virtuous in nature. Specifically, forgiveness and gratitude explained the effect on state anxiety, whereas God-related virtues (purpose in God and gratitude to God) mediated the religious effect on state depression. Finally, we found that virtues and existential belief collectively explained the religious effect on state depression and anxiety, whereas their combined mediation for intended aggression was not statistically significant, perhaps because the significant indirect effect via existential belief was negated by the non-significant mediation of the variables of virtue. In the final model, half of the mediators were found to have a direct effect on state anxiety (presence of meaning and forgiveness) and intended aggression (compassion), which implies that they might be proximate causes of the dependent variables relative to the other half.

While the direct effect of compassion on intended aggression tends to partly confirm the importance of self-control in explaining the effect of religiosity on crime (Desmond et al. 2013), the present study advances criminological research on religion by examining factors other than the major predictors of crime (i.e., deterrence, control, social learning, and strain), as Johnson and Jang (2010) called for. This study, however, did not examine those factors as alternatives to criminological variables that have been used to explain the religious effect, but rather as their complements. Thus, future research needs to explore relationships between traditional crime predictors and new explanatory factors in relation to the religion-crime association. For example, are the predictors more proximate causes of crime than virtues and a sense of meaning and purpose in life? Alternatively, are they independent of one another in explaining crime? 
Although we focused on the explanation of religious effect, this study's potential contribution goes beyond criminological research on religion. Specifically, the evidence of existential belief and virtues (i.e., compassion and forgiveness) being directly inversely related to intended aggression is consistent with the premise of "positive criminology"; that is, the explanation of crime (or lack thereof) should include not only criminogenic factors, but also "forces and effects that are experienced positively" (Ronel and Elisha 2011, p. 307; Hallett et al. 2017), such as resilience, post-traumatic growth, exposure to positive human values (e.g., altruism), identity transformation, and reintegrative shaming. For example, a recent study shows how "hitting rock bottom" or existential crisis, like imprisonment, is likely to trigger a process of developing positive self-identity, not only cognitive and emotional but also existential, which in turn contributes to reduction in crime and deviance or criminal desistance (Jang et al. 2018; Elisha et al. 2012).

A practical implication of the present finding is that religious programs in prison are likely to help offenders rehabilitate themselves by having them find new meaning and purpose in life and become virtuous through spiritual transformation, as well as religious teachings and practices. Unless offenders find self-transcendent reasons for being hopeful and optimistic about their future (e.g., God still loves them and has purpose for their lives) and become self-motivated for change, rehabilitation efforts will remain an ongoing challenge for correctional authorities. Despite their potential benefits to prisoners, religious programs should remain voluntary for offenders in prison, regardless of their rehabilitative efficacy. Conversely, efforts to restrict voluntary participation in religious programs, whether facilitated through chaplaincy programs or community volunteers, would be a mistake.

A key methodological limitation of the current study is its use of cross-sectional data in studying causal relationships. Specifically, causal ordering between religiosity and the mediators was only partly established, as the former was operationalized by three previous measures (frequency of service attendance, prayer, and reading the sacred text) and two current ones (perceived closeness to God and importance of religion), and the latter by all current measures (i.e., levels of existential belief and virtuous characteristics at the time of our survey). Furthermore, causal ordering between the mediators (current measures) and negative emotional states (previous measures of state depression and anxiety during the last one and two weeks prior to our survey, respectively) failed to meet the necessary condition of temporal order for causality, while that between the current measures of existential belief and virtues and the future measure of intended aggression did meet the necessary condition. Future research should examine these relationships using panel data. Another limitation concerns generalizability of our findings, because we studied a convenience sample of prisons, although offenders were randomly selected from each prison. As a result, the present findings are applicable only to the three prisons. Finally, we analyzed data from male prisoners only, and thus do not know whether findings would be different for female prisoners. We call for future research that examines gender differences.

In conclusion, this study shows that religion tends to have prosocial effect on mental health and behaviors among offenders in prison, as their involvement in religion is likely to help them find meaning and purpose in life and become virtuous, which is in turn expected to reduce deviance in prison (i.e., infraction) and recidivism following release from prison. The current findings also provide evidence that offenders are existential beings in need of self-transcendent meaning and purpose in life, just like any other human being, particularly when they are in extreme adversity, like imprisonment (Frankl 1984). In addition, our study implies that offenders are in essence "moral animals in that [they] ... not only have desires, beliefs, and feelings ... but also the ability and disposition to form strong evaluations about [their] desires, beliefs, and feelings that hold the potential to transform them" (Smith 2003a, pp. 8-9) despite what they did in the past. Therefore, as Cullen et al. (2001, p. 268) suggest, prisons should be considered as "moral institutions" that foster virtue in inmates, while holding them accountable "to become virtuous people and to manifest moral goodness," while the "virtuous prison" would not be suitable for all offenders. Religion or faith-based programs would play an important role for such prisons. 
Author Contributions: S.J.J. designed the study, analyzed data, and drafted the manuscript; S.J.J. and B.R.J. communicated with the Texas Department of Criminal Justice for their approval of the survey at the three prisons, sampling, and official data (criminal background information); S.J.J., B.R.J., and J.H. collected survey data; B.R.J., J.H., M.H., and G.D. edited early drafts of manuscript.

Acknowledgments: The authors gratefully acknowledge this research project stems from a larger study funded by Premier FOTO, LLC. They are also greatly indebted not only to the Executive Services of the Texas Department of Criminal Justice, but also the wardens and staff of three prisons for their invaluable support and timely cooperation for this study. The research contained in this document was coordinated in part by the Texas Department of Criminal Justice (Research Agreement \#661-AR12). The contents of this report reflect the views of the authors and do not necessarily reflect the views of the Texas Department of Criminal Justice.

Conflicts of Interest: The authors declare no conflict of interest.

\section{Appendix A}

Table A1. Variables Used in Analysis.

\begin{tabular}{|c|c|c|}
\hline Variable & $\begin{array}{l}\text { Items } \\
\text { (Response Categories) }\end{array}$ & $\begin{array}{l}\text { Factor Loading } \\
\quad(\alpha)\end{array}$ \\
\hline \multirow{8}{*}{ Religiosity } & $\begin{array}{l}\text { 1. How close do you feel to God most of time? }(1=\text { not close at all, } 2=\text { not very close, } \\
3=\text { somewhat close, } 4=\text { pretty close, } 5=\text { extremely close })\end{array}$ & $0.55(0.81)$ \\
\hline & 2. How often do you currently attend religious services at a place of worship? & \\
\hline & $\begin{array}{l}(1=\text { never, } 2=\text { less than once a year, } 3=\text { once or twice a year, } 4=\text { several times a year, } \\
5=\text { once a month, } 6=2-3 \text { times a month, } 7=\text { about weekly, } 8=\text { several times a week })\end{array}$ & 0.61 \\
\hline & About how often do you currently pray outside of religious services? & \\
\hline & $\begin{array}{l}(1=\text { never }, 2=\text { only on certain occasions, } 3=\text { once a week or less, } 4=\text { a few times a week, } \\
5=\text { once a day, } 6=\text { several times a day })\end{array}$ & 0.71 \\
\hline & 4. In general, how important is religion to you? & 066 \\
\hline & $(1=$ not at all, $2=$ somewhat, $3=$ fairly, $4=$ very, $5=$ extremely $)$ & 0.06 \\
\hline & $\begin{array}{l}\text { 5. Outside of attending religious services, about how often do you currently spend private } \\
\text { time reading the Bible, Koran, Torah, or other sacred book? }(1=\text { never, } 2=\text { less than once a } \\
\text { year, } 3=\text { once to several times a year, } 4=\text { once a month, } 5=2-3 \text { times a month, } 6=\text { about } \\
\text { weekly, } 7=\text { several times a week, } 8=\text { everyday) }\end{array}$ & 0.86 \\
\hline Variable & $\begin{array}{l}\text { Items } \\
\text { (Response Categories) }\end{array}$ & $\begin{array}{l}\text { Factor Loading } \\
\quad(\alpha)\end{array}$ \\
\hline \multirow{5}{*}{$\begin{array}{l}\text { Presence of } \\
\text { meaning }\end{array}$} & $\begin{array}{l}\text { We would like you to take a moment to think about what makes your life feel important to you. } \\
\text { Please respond to the following statements as truthfully and accurately as you can. } \\
(1=\text { absolutely untrue, } 2=\text { mostly untrue, } 3=\text { somewhat untrue, } 4=\text { can't say true or untrue, } \\
5=\text { somewhat true, } 6=\text { mostly true, } 7=\text { absolutely true) }\end{array}$ & \\
\hline & 1. I understand my life's meaning. & $0.68(0.83)$ \\
\hline & 2. My life has a clear sense of purpose. & 0.70 \\
\hline & 3. I have a good sense of what makes my life meaningful. & 0.81 \\
\hline & I have discovered a satisfying life purpose. & 0.79 \\
\hline \multirow{6}{*}{ Compassion } & $\begin{array}{l}\text { How strongly do you agree or disagree with the following statements? } \\
(1=\text { strongly disagree, } 2=\text { disagree, } 3=\text { agree, } 4=\text { strongly agree })\end{array}$ & \\
\hline & 1. When I see someone in a difficult situation I try to imagine how they feel. & $0.63(0.78)$ \\
\hline & 2. I feel compelled to help someone even when doing so requires me to go out of my way. & 0.78 \\
\hline & $\begin{array}{l}\text { 3. It's not enough to feel sorry for someone who is in trouble. Whenever it is possible, I must } \\
\text { also do something to help them. }\end{array}$ & 0.82 \\
\hline & $\begin{array}{l}\text { 4. I feel sorry for someone who is in trouble even when they caused the problem that } \\
\text { faces them. }\end{array}$ & 0.49 \\
\hline & 5. I feel sorry for someone even when they've something that hurts me. & 0.51 \\
\hline
\end{tabular}


Table A1. Cont.

\begin{tabular}{|c|c|c|}
\hline Variable & $\begin{array}{l}\text { Items } \\
\text { (Response Categories) }\end{array}$ & $\begin{array}{l}\text { Factor Loading } \\
\quad(\alpha)\end{array}$ \\
\hline \multirow{2}{*}{ Forgiveness } & $\begin{array}{l}\text { Please indicate how often you have done the following. } \\
(1=\text { never, } 2 \text { = seldom, } 3=\text { often, } 4 \text { = always) }\end{array}$ & \\
\hline & 1. I have forgiven those who hurt me. & \\
\hline \multirow{4}{*}{ Gratitude } & $\begin{array}{l}\text { Please indicate how much you agree with each of the statements, using the scale below. } \\
(1=\text { strongly disagree, } 2=\text { disagree, } 3=\text { slightly disagree, } 4=\text { neutral, } 5=\text { slightly agree, } 6=\text { agree, } \\
7=\text { strongly agree })\end{array}$ & \\
\hline & 1. If had to list everything that I felt grateful for, it would be a very long list. & $0.65(0.78)$ \\
\hline & 2. I am grateful to a wide variety of people. & 0.99 \\
\hline & $\begin{array}{l}\text { 3. As I get older I find myself more able to appreciate the people, events, and situations that } \\
\text { have been part of my life history. }\end{array}$ & 0.66 \\
\hline \multirow{4}{*}{$\begin{array}{l}\text { God's } \\
\text { purpose in life }\end{array}$} & $\begin{array}{l}\text { How strongly do you agree or disagree with the following statements? } \\
(1=\text { strongly disagree, } 2=\text { disagree, } 3=\text { agree, } 4=\text { strongly agree })\end{array}$ & \\
\hline & 1. God put me in this life for a purpose. & $0.86(0.91)$ \\
\hline & 2. God has a specific plan for my life. & 0.89 \\
\hline & 3. God has reason for everything that happens to me. & 0.87 \\
\hline \multirow{3}{*}{$\begin{array}{l}\text { Gratitude to } \\
\text { God }\end{array}$} & $\begin{array}{l}\text { Please indicate how much you agree with each of the statements. } \\
(1=\text { strongly disagree, } 2 \text { = disagree, } 3=\text { neutral, } 4 \text { = agree, } 5=\text { strongly agree) }\end{array}$ & \\
\hline & 1. I am grateful to God for all He has done for me. & $(0.74)$ \\
\hline & 2. I am grateful to God for all He has done for my family members and close friends. & \\
\hline Variable & $\begin{array}{l}\text { Items } \\
\text { (Response Categories) }\end{array}$ & $\begin{array}{l}\text { Factor loading } \\
\quad(\alpha)\end{array}$ \\
\hline \multirow{9}{*}{$\begin{array}{c}\text { State } \\
\text { depression }\end{array}$} & $\begin{array}{l}\text { During the past week, how often have you felt or experienced the following? } \\
\text { ( } 1=\text { never, } 2=\text { rarely, } 3=\text { sometimes, } 4=\text { often, } 5=\text { very often })\end{array}$ & \\
\hline & 1. I felt I could not shake off the blues, even with the help of others. & $0.61(0.87)$ \\
\hline & 2. I felt depressed. & 0.90 \\
\hline & 3. I felt sad. & 0.80 \\
\hline & 4. I did not feel like eating, and my appetite was poor. & 0.58 \\
\hline & 5. I felt that everything I did was an effort. & 0.51 \\
\hline & 6. My sleep was restless. & 0.74 \\
\hline & 7. I could not get going. & 0.80 \\
\hline & 8. I felt suicidal. & 0.48 \\
\hline \multirow{8}{*}{ State anxiety } & $\begin{array}{l}\text { Over the last } 2 \text { weeks, how often have you been bothered by any of the following problems? } \\
(1=\text { never, } 2 \text { = rarely, } 3=\text { sometimes, } 4=\text { often, } 5=\text { very often })\end{array}$ & \\
\hline & 1. Feeling nervous, anxious & $0.68(0.91)$ \\
\hline & 2. Not being able to stop or control worrying & 0.80 \\
\hline & 3. Trouble relaxing & 0.84 \\
\hline & 4. Being so restless that it is hard to sit still & 0.78 \\
\hline & 5. Worrying too much about different things & 0.84 \\
\hline & 6. Becoming easily annoyed or irritable & 0.71 \\
\hline & 7. Feeling afraid as if something awful might happen & 0.72 \\
\hline
\end{tabular}




\section{Appendix B}

Table A2. Measurement Models: Full Model.

\begin{tabular}{|c|c|c|c|c|c|c|c|c|}
\hline Item & Religiosity & $\begin{array}{c}\text { Presence of } \\
\text { Meaning }\end{array}$ & Compassion & Gratitude & $\begin{array}{c}\text { God's } \\
\text { Purpose }\end{array}$ & $\begin{array}{l}\text { Gratitude } \\
\text { to God }\end{array}$ & $\begin{array}{c}\text { State } \\
\text { Depression }\end{array}$ & $\begin{array}{c}\text { State } \\
\text { Anxiety }\end{array}$ \\
\hline (1) & $0.59 * *$ & $0.70 * *$ & $0.62 * *$ & $0.76^{* *}$ & $0.86^{* *}$ & $0.85^{* *}$ & $0.61^{* *}$ & $0.67 * *$ \\
\hline (2) & $0.57^{* *}$ & $0.68 * *$ & $0.78^{* *}$ & $0.87 * *$ & $0.88 * *$ & $0.46^{* *}$ & $0.88^{* *}$ & $0.80 * *$ \\
\hline (3) & $0.73^{* *}$ & $0.82 * *$ & $0.84^{* *}$ & & 0.88 ** & $0.67 * *$ & $0.77 * *$ & $0.84^{* *}$ \\
\hline (4) & $0.68 * *$ & $0.78 * *$ & $0.46 * *$ & & & & $0.60 * *$ & $0.79 * *$ \\
\hline (5) & $0.84^{* *}$ & & $0.51 * *$ & & & & $0.50 * *$ & $0.85^{* *}$ \\
\hline (6) & & & & & & & $0.75^{* *}$ & $0.73 * *$ \\
\hline (7) & & & & & & & $0.81 * *$ & $0.73^{* *}$ \\
\hline (8) & & & & & & & $0.51 * *$ & \\
\hline
\end{tabular}

Indicators (1) to (8) correspond to items 1 to 8 in Appendix A. ${ }^{* *} p<0.01$ (one-tailed test).

\section{References}

Agnew, Robert. 2006. Pressured into Crime: An Overview of General Strain Theory. Los Angeles: Roxbury Publishing Company.

Akers, Ronald L. 2009. Social Learning and Social Structure: A General Theory of Crime and Deviance. New Brunswick: Transaction.

Aneshensel, Carol S. 1992. Social Stress-Theory and Research. Annual Review of Sociology 18: 15-38. [CrossRef]

Baier, Colin J., and Bradley R. E. Wright. 2001. "If You Love Me, Keep My Commandments": A Meta-Analysis of the Effect of Religion on Crime. Journal of Research in Crime and Delinquency 38: 3-21. [CrossRef]

Baraldi, Amanda N., and Craig K. Enders. 2010. An Introduction to Modern Missing Data Analyses. Journal of School Psychology 48: 5-37. [CrossRef] [PubMed]

Batson, C. Daniel, and Eric L. Stocks. 2004. Religion: Its Core Psychological Functions. In Handbook of Experimental Existential Psychology. Edited by Jeff Greenberg, Sander Leon Koole and Thomas Pyszczynski. New York: Guilford Press, pp. 141-55.

Batson, C. Daniel, Randy B. Floyd, Julie M. Meyer, and Alana L. Winner. 1999. "And Who is My Neighbor?:” Intrinsic Religion as a Source of Universal Compassion. Journal for the Scientific Study of Religion 38: 445-57. [CrossRef]

Bernard, Mathieu, Florian Strasser, Claudia Gamondi, Giliane Braunschweig, Michaela Forster, Karin Kaspers-Elekes, Silvia W. Veri, Gian D. Borasio, and SMILE Consortium Team. 2017. Relationship between Spirituality, Meaning in Life, Psychological Distress, Wish for Hastened Death, and their Influence on Quality of Life in Palliative Care Patients. Journal of Pain and Symptom Management 54: 514-22. [CrossRef] [PubMed]

Blevins, Kristie R., Shelley Johnson Listwan, Francis T. Cullen, and Cheryl L. Jonson. 2010. A General Strain Theory of Prison Violence and Misconduct: An Integrated Model of Inmate Behavior. Journal of Contemporary Criminal Justice 26: 148-66. [CrossRef]

Bollen, Kenneth A. 1989. Structural Equations with Latent Variables. New York: John Wiley \& Sons.

Burkett, Steven R., and Bruce O. Warren. 1987. Religiosity, Peer Association, and Adolescent Marijuana use: A Panel Study of Underlying Causal Structures. Criminology 25: 109-32. [CrossRef]

Cullen, Francis T., Jody Sundt, and John F. Wozniak. 2001. The Virtuous Prison: Toward a Restorative Rehabilitation. In Contemporary Issues in Crime and Criminal Justice: Essays in Honor of Gilbert Geis. Edited by Henry N. Pontell and David Schichor. Upper Saddle River: Prentice Hall, pp. 265-86.

Davis, Don E., Joshua N. Hook, Ryan McAnnally-Linz, Elise Choe, and Vanessa Placeres. 2017. Humility, Religion, and Spirituality: A Review of the Literature. Psychology of Religion and Spirituality 9: 242-53. [CrossRef]

Desmond, Scott A., Sarah E. Soper, and Rachel Kraus. 2011. Religiosity, Peers, and Delinquency: Does Religiosity Reduce the Effect of Peers on Delinquency? Sociological Spectrum 31: 665-94. [CrossRef]

Desmond, Scott A., Jeffery T. Ulmer, and Christopher D. Bader. 2013. Religion, Self Control, and Substance Use. Deviant Behavior 34: 384-406. [CrossRef]

Elisha, Ety, Yael Idisis, and Natti Ronel. 2012. Window of Opportunity: Social Acceptance and Life Transformation in the Rehabilitation of Imprisoned Sex Offenders. Aggression and Violent Behavior 17: 323-32. [CrossRef]

Ellison, Christopher G. 1991. Religious Involvement and Subjective Well-Being. Journal of Health and Social Behavior 32: 80-99. [CrossRef] [PubMed] 
Emmons, Robert A., and Cheryl A. Crumpler. 2000. Gratitude as a Human Strength: Appraising the Evidence. Journal of Social and Clinical Psychology 19: 56-69. [CrossRef]

Emmons, Robert A., and Michael E. McCullough. 2003. Counting Blessings Versus Burdens: An Experimental Investigation of Gratitude and Subjective Well-being in Daily Life. Journal of Personality and Social Psychology 84: 377. [CrossRef] [PubMed]

Emmons, Robert A., and Raymond F. Paloutzian. 2003. The Psychology of Religion. Annual Review of Psychology 54: 377-402. [CrossRef] [PubMed]

Evans, T. David, Francis T. Cullen, R. Gregory Dunaway, and Velmer S. Burton. 1995. Religion and Crime Reexamined-The Impact of Religion, Secular Controls, and Social Ecology on Adult Criminality. Criminology 33: 195-224. [CrossRef]

Frankl, Viktor E. 1984. Man's Search for Meaning. New York: Pocket Books. First published 1946.

Frankl, Viktor E. 1986. The Doctor and the Soul: From Psychotherapy to Logotherapy. New York: Vintage Books.

Froh, Jeffrey J., William J. Sefick, and Robert A. Emmons. 2008. Counting Blessings in Early Adolescents: An Experimental Study of Gratitude and Subjective Well-Being. Journal of School Psychology 46: 213-33. [CrossRef] [PubMed]

Fry, Prem S. 2000. Religious Involvement, Spirituality and Personal Meaning for Life: Existential Predictors of Psychological Wellbeing in Community-Residing and Institutional Care Elders. Aging \& Mental Health 4: 375-87.

George, Linda K., Christopher G. Ellison, and David B. Larson. 2002. Explaining the Relationships between Religious Involvement and Health. Psychological Inquiry 13: 190-200. [CrossRef]

Gibbs, Jack P. 1986. Punishment and Deterrence: Theory, Research, and Penal Policy. In Law and the Social Sciences. Edited by Leon Lipson and Stanton Wheeler. New York: Russell Sage, pp. 319-68.

Giordano, Peggy C., Stephen A. Cernkovich, and Jennifer L. Rudolph. 2002. Gender, Crime, and Desistance: Toward a Theory of Cognitive Transformation. American Journal of Sociology 107: 990-1064. [CrossRef]

Giordano, Peggy C., Ryan D. Schroeder, and Stephen A. Cernkovich. 2007. Emotions and Crime over the Life Course: A Neo-Meadian Perspective on Criminal Continuity and Change. American Journal of Sociology 112: 1603-61. [CrossRef]

Goffman, Erving. 1961. On the Characteristics of Total Institutions. In Symposium on Preventive and Social Psychiatry. Washington: Walter Reed Army Medical Centre, pp. 43-84.

Gottfredson, Michael R., and Travis Hirschi. 1990. A General Theory of Crime. Stanford: Stanford University Press.

Graham, John W. 2009. Missing Data Analysis: Making it Work in the Real World. Annual Review of Psychology 60: 549-76. [CrossRef] [PubMed]

Hackney, Charles H., and Glenn S. Sanders. 2003. Religiosity and Mental Health: A Meta-Analysis of Recent Studies. Journal for the Scientific Study of Religion 42: 43-55. [CrossRef]

Hallett, Michael, Joshua Hays, Byron R. Johnson, Sung Joon Jang, and Grant Duwe. 2017. The Angola Prison Seminary: Effects of Faith-Based Ministry on Identity Transformation, Desistance, and Rehabilitation. New York: Routledge.

Hayward, R. David, and Neal Krause. 2014. Religion, Mental Health, and Well-Being Social Aspects. In Religion, Personality, and Social Behavior. Edited by Vassilis Saroglou. New York: Psychology Press, pp. 255-80.

Hirschi, Travis. 1969. Causes of Delinquency. Berkeley: University of California Press.

$\mathrm{Hu}$, Li-tze, and Peter M. Bentler. 1999. Cutoff Criteria for Fit Indexes in Covariance Structure Analysis: Conventional Criteria Versus New Alternatives. Structural Equation Modeling 6: 1-55. [CrossRef]

Jang, Sung Joon. 2016. Existential Spirituality, Religiosity, and Symptoms of Anxiety-Related Disorders: A Study of Belief in Ultimate Truth and Meaning in Life. Journal of Psychology and Theology 44: 213-29. [CrossRef]

Jang, Sung Joon, and Aaron B. Franzen. 2013. Is being "Spiritual" enough without being Religious? A Study of Violent and Property Crimes among Emerging Adults. Criminology 51: 595-627. [CrossRef]

Jang, Sung Joon, and Byron R. Johnson. 2004. Explaining Religious Effects on Distress among African Americans. Journal for the Scientific Study of Religion 43: 239-60. [CrossRef]

Jang, Sung Joon, and Byron R. Johnson. 2011. The Effects of Childhood Exposure to Drug Users and Religion on Drug use in Adolescence and Young Adulthood. Youth E Society 43: 1220-45.

Jang, Sung Joon, and Byron R. Johnson. 2017. Religion, Spirituality, and Desistance from Crime. In The Routledge International Handbook of Life-Course Criminology. Edited by Arjan Blockland and Victor van der Geest. Oxford: Routledge, pp. 74-86. 
Jang, Sung Joon, Byron R. Johnson, Joshua Hays, Michael Hallett, and Grant Duwe. 2018. Religion and Misconduct in "Angola" Prison: Conversion, Congregational Participation, Religiosity, and Self-Identities. Justice Quarterly 35: 412-42. [CrossRef]

Johnson, Byron R. 2011. More God, Less Crime: Why Faith Matters and How it Could Matter More. West Conshohocken: Templeton Press.

Johnson, Byron R., and Sung Joon Jang. 2010. Crime and Religion: Assessing the Role of the Faith Factor. In Contemporary Issues in Criminological Theory and Research: The Role of Social Institutions. Edited by Richard Rosenfeld, Kenna Quinet and Crystal A. Garcia. Belmont: Wadsworth, pp. 117-49.

Johnson, Byron R., Sung Joon Jang, David B. Larson, and Spencer D. Li. 2001. Does Adolescent Religious Commitment Matter? A Reexamination of the Effects of Religiosity on Delinquency. Journal of Research in Crime and Delinquency 38: 22-44. [CrossRef]

Kelly, P. Elizabeth, Joshua R. Polanin, Sung Joon Jang, and Byron R. Johnson. 2015. Religion, Delinquency, and Drug use: A Meta-Analysis. Criminal Justice Review 40: 505-23. [CrossRef]

Koenig, Harold G., Dana G. King, and Verna B. Carson. 2012. Handbook of Religion and Health. New York: Oxford University Press.

Krause, Neal. 2018. Assessing the Relationships among Religion, Humility, Forgiveness, and Self-Rated Health. Research in Human Development 15: 33-49. [CrossRef]

Krause, Neal, Berit Ingersoll-Dayton, Jersey Liang, and Hidehiro Sugisawa. 1999. Religion, Social Support, and Health among the Japanese Elderly. Journal of Health and Social Behavior 40: 405-21. [CrossRef] [PubMed]

Krause, Neal, Kenneth I. Pargament, Peter C. Hill, and Gail Ironson. 2016. Humility, Stressful Life Events, and Psychological Well-being: Findings from the Landmark Spirituality and Health Survey. The Journal of Positive Psychology 11: 499-510. [CrossRef]

Levin, Jeff. 2010. Religion and Mental Health: Theory and Research. International Journal of Applied Psychoanalytic Studies 7: 102-15. [CrossRef]

Martos, Tamas, Barna K. Thege, and Michael F. Steger. 2010. It's Not Only what You Hold, it's how You Hold it: Dimensions of Religiosity and Meaning in Life. Personality and Individual Differences 49: 863-68. [CrossRef]

McCullough, Michael E. 2000. Forgiveness as Human Strength: Theory, Measurement, and Links to Well-Being. Journal of Social and Clinical Psychology 19: 43-55. [CrossRef]

McCullough, Michael E., Robert A. Emmons, and Jo-Ann Tsang. 2002. The Grateful Disposition: A Conceptual and Empirical Topography. Journal of Personality and Social Psychology 82: 112. [CrossRef] [PubMed]

McKnight, Patrick E., and Todd B. Kashdan. 2009. Purpose in Life as a System that Creates and Sustains Health and Well-being: An Integrative, Testable Theory. Review of General Psychology 13: 242-51. [CrossRef]

Mirowsky, John, and Catherine E. Ross. 2003. Social Causes of Psychological Distress. Hawthorne: Aldine De Gruyter.

Moreira-Almeida, Alexander, Francisco L. Neto, and Harold G. Koenig. 2006. Religiousness and Mental Health: A Review. Revista Brasileira De Psiquiatria 28: 242-50. [CrossRef] [PubMed]

Muthén, Bengt O. 1983. Latent Variable Structural Equation Modeling with Categorical-Data. Journal of Econometrics 22: 43-65. [CrossRef]

Muthén, Linda K., and Bengt O. Muthén. 2017. Mplus User's Guide. Los Angeles: Muthén \& Muthén.

Paternoster, Raymond, and Shawn D. Bushway. 2009. Desistance and the "Feared Self": Toward an Identity Theory of Criminal Desistance. Journal of Criminal Law and Criminology 99: 1103-56.

Pearlin, Leonard I. 1989. The Sociological Study of Stress. Journal of Health and Social Behavior 30: 241-56. [CrossRef] [PubMed]

Radloff, Lenore S. 1977. The CES-D Scale: A Self-Report Depression Scale for Research in the General Population. Applied Psychological Measurement 1: 385-401. [CrossRef]

Reisig, Michael D., Scott E. Wolfe, and Travis C. Pratt. 2012. Low Self-Control and the Religiosity-Crime Relationship. Criminal Justice and Behavior 39: 1172-91. [CrossRef]

Roberts, Robert C. 2004. The Blessings of Gratitude: A Conceptual Analysis. In The Psychology of Gratitude. Oxford: Oxford University Press, pp. 58-78.

Ronel, Natti, and Ety Elisha. 2011. A Different Perspective: Introducing Positive Criminology. International Journal of Offender Therapy and Comparative Criminology 55: 305-25. [CrossRef] [PubMed]

Rye, Mark S., Kenneth I. Pargament, M. Amir Ali, Guy L. Beck, Elliot N. Dorff, Charles Hallisey, Vasudha Narayanan, and James G. Williams. 2000. Religious Perspectives on Forgiveness. In Forgiveness: Theory, Research, and Practice. New York: The Guilford Press, pp. 17-40. 
Sawatzky, Rick, Pamela A. Ratner, and Lyren Chiu. 2005. A Meta-Analysis of the Relationship between Spirituality and Quality of Life. Social Indicators Research 72: 153-88. [CrossRef]

Smith, Christian. 2003a. Moral, Believing Animals: Human Personhood and Culture. New York: Oxford University Press.

Smith, Christian. 2003b. Theorizing Religious Effects among American Adolescents. Journal for the Scientific Study of Religion 42: 17-30. [CrossRef]

Spitzer, Robert L., Kurt Kroenke, Janet B. Williams, and Bernd Löwe. 2006. A Brief Measure for Assessing Generalized Anxiety Disorder: The GAD-7. Archives of Internal Medicine 166: 1092-97. [CrossRef] [PubMed]

Steffen, Patrick R., and Kevin S. Masters. 2005. Does Compassion Mediate the Intrinsic Religion-Health Relationship? Annals of Behavioral Medicine 30: 217-24. [CrossRef] [PubMed]

Steger, Michael F., and Patricia Frazier. 2005. Meaning in Life: One Link in the Chain from Religiousness to Well-being. Journal of Counseling Psychology 52: 574. [CrossRef]

Steger, Michael F., Patricia Frazier, Shigehiro Oishi, and Matthew Kaler. 2006. The Meaning in Life Questionnaire: Assessing the Presence of and Search for Meaning in Life. Journal of Counseling Psychology 53: 80. [CrossRef]

Ulmer, Jeffery T., Scott A. Desmond, Sung Joon Jang, and Byron R. Johnson. 2012. Religious Involvement and Dynamics of Marijuana use: Initiation, Persistence, and Desistence. Deviant Behavior 33: 448-68. [CrossRef]

Vanhooren, Siebrecht, Mia Leijssen, and Jessie Dezutter. 2017. Loss of Meaning as a Predictor of Distress in Prison. International Journal of Offender Therapy and Comparative Criminology 61: 1411-32. [CrossRef] [PubMed]

Wang, Zhizhong, Harold G. Koenig, Hui Ma, and Saad A. Shohaib. 2016. Religion, Purpose in Life, Social Support, and Psychological Distress in Chinese University Students. Journal of Religion and Health 55: 1055-64. [CrossRef] [PubMed]

(C) 2018 by the authors. Licensee MDPI, Basel, Switzerland. This article is an open access article distributed under the terms and conditions of the Creative Commons Attribution (CC BY) license (http:/ / creativecommons.org/licenses/by/4.0/). 